\title{
Lokalt eller sentralt?
}

Det var klare meninger om sykehusorganisering også i mellomkrigstiden (Tidsskr Nor Lægeforen 1938;

58: 1428-35). Kjenner du igjen argumentene?

\section{Enkelte bemerkninger om planleggelse av sykehusbygging fra medisinsk synspunkt.}

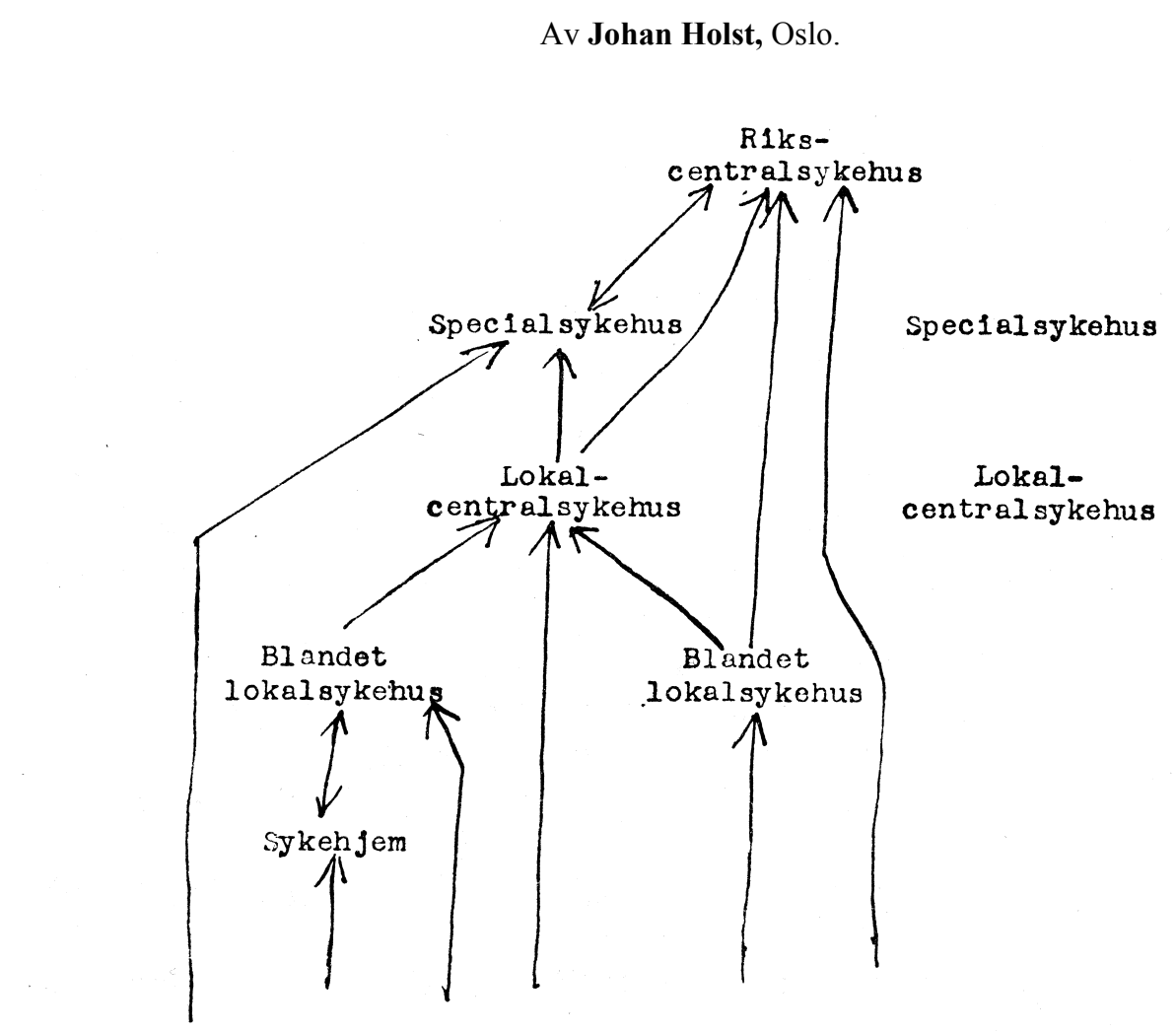

Skjema av moderne sykehusorganisasjon. Pilene viser hvorledes patientene dels innlegges direkte i de forskjellige kategorier av sykehus, dels overføres fra den ene til den annen av disse kategorier.

(...) Manglene i vårt sykehusvesen - og de er åpenbare - kan ikke tilskrives manglende offervilje hos land og folk. For hvor det gjelder å bevilge og å bruke penger til sykehusbygging står vårt land blandt de første $i$ verden. Det er hvor det gjelder å utnytte, å få valuta for de pengene man bruker, at vi står tilbake, - $\mathrm{i}$ visse henseender endog langt tilbake. Hvorfor? Fordi der ved utviklingen av vårt sykehusvesen er tatt for lite hensyn til sakkyndighet, samarbeide og langsiktig planleggelse.

(...)

Vedstående skjema gir et inntrykk av vekselvirkningen mellem disse forskjellige kategorier av sykehus, som ikke skal konkurrere, men supplere hverandre. Hver enkelt av disse sykehuskategorier representerer et hjul i et felles maskineri som er det hele lands sykehusvesen. Dette sykehusvesen blir ikke effektivt, maskineriet går i stå, hvis det er et enkelt hjul som mangler eller som ikke virker som det skal.

Skjemaet viser også, at hvis dette maskineri virker, så vil selv den minste by eller bygd for sine innbyggere få adgang til det veldige maktmiddel $i$ kampen mot sykdom som et fullt organisert, moderne sykehusvesen er. Men forsøker hver liten by eller hver liten bygd å være sig selv nok på sykehusbyggingens område, så avskjærer den sig adgang til en vesentlig del av den moderne medisinens maktmidler, nemlig alt det som ligger utenfor et lite, blandet lokal-sykehus' ydeevne.

Ja selv et fylke eller en større by med lokal-centralsykehus kan ikke isolere sig sykehusmessig sett, uten å avskjære sig adgang til den vesentlige tilvekst $\mathrm{i}$ medisinske hjelpemidler som riks-centralsykehus og spesialsykehus betyr. 